JeMAS 11 (2) (2016) xx-xx
Jitt://journal.unnes.ac.id/nju/index.php/kemas

\title{
POTENSI PENDIDIKAN GIZI DALAM MENINGKATKAN ASUPAN GIZI PADA REMAJA PUTRI YANG ANEMIA DI KOTA MEDAN
}

\author{
Verarica Silalahio $^{1 凶}$, Evawany Aritonang ${ }^{2}$, Taufik Ashar ${ }^{3}$ \\ ${ }^{1}$ Alumni Program Studi S2 FKM USU \\ ${ }^{2}$ Staf Pengajar Departemen Gizi FKM USU \\ ${ }^{3}$ Staf Pengajar Departemen Kesehatan Lingkungan FKM USU
}

\section{Info Artikel}

Sejarah Artikel:

Diterima 21 Oktober 2015

Disetujui 15 Januari 2016

Dipublikasikan Januari 2016

Keywords:

Nutrition Education;

Nutrient Intake;

Adolescent Girls; Anemia.

DOI

http://dx.doi.org/10.15294/

kemas.v11i1.3521

\begin{abstract}
Abstrak
Remaja putri merupakan kelompok anemia berisiko tinggi dibandingkan putra dengan prevalensi di Indonesia 26,5\%. Penelitian quasy experiment dengan desain pre-post intervention bertujuan menganalisis pengaruh pendidikan gizi terhadap pengetahuan gizi dan konsumsi zat gizi remaja putri. Sampel berjumlah 51 orang yang dilakukan di SMP Negeri 21 Medan tahun 2015. Pendidikan gizi diberikan dua kali dengan metode ceramah, tanya jawab dengan booklet. Asupan gizi diketahui dengan metode food recall 24 jam (dua kali). Hasil menunjukkan bahwa skor pengetahuan gizi meningkat dari $62,39 \pm 12,05$ poin menjadi $72,31 \pm 17,01$ poin. Asupan gizi (protein, vitamin C, vitamin A, asam folat, besi, zink, tembaga) mengalami penurunan sesudah intervensi. Ada perbedaan bermakna $(p<0,05)$ skor pengetahuan gizi sebelum dan sesudah intervensi. Tidak ada perbedaan $(p>0,05)$ asupan gizi sebelum dan sesudah intervensi. Hasil ini menunjukkan bahwa pendidikan gizi hanya meningkatkan pengetahuan gizi remaja putri, tetapi tidak meningkatkan asupan gizi.
\end{abstract}

\section{POTENTIAL FOR NUTRITION EDUCATION IN IMPROVING NUTRITION INTAKE IN ADOLESCENT WHICH ANEMIA IN MEDAN}

\begin{abstract}
Adolescent girls are high risk to anemia rather than boys with prevalence in Indonesia $26,5 \%$. This quasy experiment research with pretest-posttest group design study aimed to analyze effect of nutrition education on knowledge and nutrition consumption in adolescent girls. Samples with 51 subjects was conducted in Junior High School 21 Medan in 2015. The nutrition education was given twice using lecture \& question answer with booklet. Nutrition consumption was gathered twice with food recall 24 hours method. The results showed that knowledge nutrition score increased from $62.39 \pm 12.05$ points to $72.31 \pm 17.01$ points. Nutrients intake (protein, vitamin C, Vitamin A, folic acid, iron, zink, copper) decreased in the post intervention. There was a significant difference $(p<0.05)$ nutrition $k$ nowledge pre and post intervention, and no difference $(p>0.05)$ nutrition consumption pre and post intervention. This imply that nutrition education only improved the adolescent girls' knowledge nutrition, but did not improved the nutrient intake.
\end{abstract}

(c) 2016 Universitas Negeri Semarang

\begin{tabular}{lr}
\hline Alamat korespondensi: & ISSN 1858-1196 \\
Program Studi S2 FKM USU & \\
Email : verasilalahi@rocketmail.com &
\end{tabular}




\section{Pendahuluan}

Anemia masih merupakan masalah kesehatan utama masyarakat dunia, khususnya di negara sedang berkembang (WHO, 2008; Milman, 2011). Sekitar 50-80\% anemia di dunia disebabkan kekurangan zat besi (Milman, 2011). Prevalensi anemia pada remaja wanita (usia 15-19 tahun) sebesar 26,5\% dan pada wanita subur sebesar 26,9\% (Depkes RI, 2005). Berdasarkan hasil Riskesdas 2013, proporsi anemia di Indonesia pada kelompok umur 5-14 tahun adalah sebesar 26,4\% (Kemenkes RI, 2014).

Remaja putri merupakan kelompok risiko tinggi mengalami anemia dibandingkan remaja putra dimana kebutuhan absorpsi zat besi memuncak pada umur 14-15 tahun pada remaja putri, sedangkan pada remaja putra satu atau dua tahun berikutnya (WHO, 2011). Faktor risiko utama anemia defisiensi besi adalah asupan zat besi yang rendah, penyerapan zat besi yang buruk, dan periode kehidupan ketika kebutuhan akan zat besi tinggi seperti pada masa pertumbuhan, kehamilan, dan menyusui. Kekurangan zat gizi lainnya seperti vitamin A, $\mathrm{B} 12$, folat, riboflavin, dan tembaga $(\mathrm{Cu})$ serta adanya penyakit akut dan infeksi kronis seperti malaria, kanker, tuberkulosis, dan HIV juga dapat meningkatkan risiko anemia (WHO, 2008; Milman, 2011). Selain itu kebutuhan zat besi yang tinggi pada remaja putri juga pada masa menstruasi (WHO, 2008).

Asupan gizi besi yang kurang pada remaja dapat disebabkan pengetahuan remaja yang kurang tentang pangan sumber zat besi dan peran zat besi bagi remaja. Berdasarkan hal ini maka peningkatan pengetahuan melalui pendidikan gizi dapat memperbaiki perilaku remaja untuk mengonsumsi pangan sumber zat besi sesuai dengan kebutuhan gizinya. Berbagai riset telah membuktikan bahwa pendidikan gizi dapat mengubah perilaku yang baik. Goldberg (2015), menyatakan adanya pendidikan gizi tentang alkohol dapat mengubah perilaku yang dapat mencegah obesitas selama lebih dari dua dekade. Selain itu, pendidikan gizi terbukti sangat efektif untuk mencegah osteodystrophy pada pasien hemodialisis (Karavetian, 2015). Penelitian tentang intervensi pendidikan seksual yang dilakukan oleh Purwati (2015), menemukan bahwa pengetahuan kelompok yang diberikan intervensi pendidikan seksual secara signifikan lebih baik daripada sebelum diberikan pendidikan seksual.

Dampak anemia pada remaja putri dan status gizi yang buruk memberikan kontribusi negatif bila hamil pada usia remaja ataupun saat dewasa yang dapat menyebabkan kelahiran bayi dengan berat badan lahir rendah, kesakitan bahkan kematian pada ibu dan bayi. Selain itu, anemia juga mempunyai dampak negatif terhadap perkembangan fisik dan kognitif remaja (WHO, 2008). Sel darah putih yang berperan sebagai komponen imunitas tubuh tidak dapat bekerja secara efektif dalam keadaan defisiensi besi. Selain itu enzim mieloperoksidase yang berperan dalam sistem kekebalan juga terganggu fungsinya bila defisiensi besi (Almatsier, 2007). Hal yang sama juga dinyatakan oleh Barasi (2009) yaitu anemia defisiensi besi dapat memengaruhi fungsi sel darah putih sehingga menurunkan kemampuannya untuk menghancurkan organisme yang menyerang.

Meskipun dampak anemia sangat membahayakan terhadap kesehatan remaja dan prevalensi anemia pada usia 5-14 tahun cukup tinggi yaitu 26,4\% (Kemenkes RI, 2014), namun program pemerintah khusus untuk pencegahan anemia remaja saat ini tidak ada. Berbeda dengan program suplementasi besi, program pemberian makanan tambahan, pendidikan gizi hanya ditujukan untuk penanggulangan anemia pada ibu hamil. Dibandingkan dengan program suplementasi dan program pemberian makanan tambahan yang sangat mahal biayanya, maka pendidikan gizi merupakan program dengan biaya lebih murah. Dalam kondisi ekonomi sulit di Indonesia saat ini maka pendidikan gizi merupakan intervensi yang tepat dalam mengatasi anemia pada remaja.

Survei pendahuluan oleh peneliti dan petugas Usaha Kesehatan Sekolah (UKS) Puskesmas Simalingkar menemukan bahwa remaja putri di SMP Negeri 21 Medan diduga anemia karena sering mengalami pusing, lemas dan ngantuk di kelas yang merupakan gejala anemia. Hasil pemeriksaan hemoglobin di SMP Negeri 21 Medan didapatkan sebanyak 76 remaja putri $(88,37 \%)$ mengalami anemia. Hal ini menandakan bahwa anemia menjadi 
masalah kesehatan pada kelompok remaja putri di lokasi tersebut.

Pemberian pendidikan gizi pada remaja putri diharapkan dapat menambah pengetahuan remaja putri tentang gizi khusunya tentang anemia, dan diharapkan dapat mengubah pola makan sehingga asupan gizi menjadi lebih baik. Pemikiran yang terbuka dan karakteristik remaja yang masih dalam tahap belajar secara tidak langsung akan memengaruhi kebiasaan mereka. Dengan pendidikan gizi, remaja akan lebih mengenal kebiasaan baik dalam hal pemenuhan kebutuhan asupan gizi, sehingga dapat mempraktikannya dalam kehidupan sehari-hari.

Berdasarkan hal ini maka penelitian bertujuan (1) menganalisis efek pendidikan gizi terhadap pengetahuan gizi, (2) menganalisis efek pendidikan gizi terhadap asupan zat gizi (protein, vitamin C, vitamin A, asam folat, besi, zink dan tembaga).

\section{Metode}

Jenis penelitian adalah quasy experiment dengan rancangan pretest-posttest group di SMP Negeri 21 Medan. Populasi adalah seluruh remaja putri yang anemia. Sampel adalah total populasi yang dipilih dengan kriteria inklusi dan eksklusi. Kriteria inklusi : 1) aktif sekolah dan datang ketika dilakukan pemeriksaan darah, 2) sehat dan tidak sakit diare, TBC, atau penyakit lain saat penelitian, 3) tinggal bersama orang tua dan 4) bersedia mengikuti penelitian dengan mengisi informed consent. Kriteria eksklusi: 1) sedang menstruasi ketika pemeriksaan darah dilakukan, 2) dalam tiga bulan terakhir mengonsumsi suplemen besi, 3) pekerjaan orang tua dibidang kesehatan, 4) pendidikan orang tua lebih dari lulusan Sekolah Menengah Atas (SMA), dan 5) penghasilan orang di atas dua juta per bulan. Setelah penerapan kriteria inklusi dan eksklusi, maka 51 remaja putri sebagai sampel.

Data karakteristik sampel dan karakteristik keluarga(pendidikan dan pekerjaan orang tua) dikumpulkan menggunakan kuesioner. Data anemia awal diperoleh dengan pemeriksaan darah menggunakan alat Easy Touch GCHb oleh tenaga medis terlatih. Data asupan gizi dikumpulkan dengan formulir food recall 24 hours dan dianalisis dengan program nutri survey. Efek pendidikan gizi diukur dengan perubahan pengetahuan dan tindakan remaja melalui 25 pertanyaan dengan topik pengertian, orang yang berisiko, faktor risiko, tanda dan akibat anemia, cara pencegahan dan cara penanggulangan serta zat-zat gizi yang berhubungan dengan anemia. Sebelum intervensi, sampel diberikan pretest pengetahuan gizi, dan asupan zat gizi (protein, vitamin $C$, vitamin $A$, asam folat, besi, zink dan tembaga). Intervensi pendidikan gizi diberikan dua kali selama delapan minggu menggunakan metode ceramah dan tanya jawab dengan booklet. Pada akhir penelitian dilakukan postest pengetahuan gizi dan asupan zat gizi (protein, vitamin $\mathrm{C}$, vitamin $\mathrm{A}$, asam folat, besi, zink dan tembaga).

Efek pendidikan gizi terhadap asupan zat gizi dianalisis dengan uji beda pengetahuan gizi, dan asupan gizi. Bila data berdistribusi normal, maka analisis dilakukan dengan uji statistik parametrik yaitu uji t berpasangan. Sebaliknya, bila data tidak berdistribusi normal, maka digunakan uji statistik non parametrik yaitu uji Wilcoxon.

\section{Hasil dan Pembahasan}

Karakteristik Keluarga dilihat dari tingkat pendidikan, pekerjaan orang tua dan status kepemilikan rumah. Berdasarkan alat bantu kuesioner yang digunakan, didapatkan bahwa pendidikan ayah dan ibu hanya terdiri dari dua tingkat pendidikan, yaitu SMP dan SMA. Pendidikan berada dalam kategori rendah yaitu dominan SMP $(52,9 \%$ pada tingkat pendidikan ayah dan $84,3 \%$ pada tingkat pendidikan ibu). Pekerjaan ayah beragam dan paling banyak kategori lain-lain (satpam, supir, bengkel, tukang parkir, tukang becak, tukang cuci, tukang urut, pemusik, dan penjahit) sebesar $41,2 \%$, sedangkan pekerjaan ibu terbanyak adalah tidak bekerja $(74,5 \%)$ atau status ibu rumah tangga. Pekerjaan ayah dan ibu ini diasumsikan mempunyai pendapatan yang rendah. Berdasarkan status kepemilikan rumah didapatkan bahwa sebagian besar keluarga sampel tinggal di dalam rumah kontrakan $(58,8 \%)$. Hal ini mengasumsikan bahwa spemenuhan kebutuhan gizi keluarga juga akan dipengaruhi oleh pendapatan yang harus dikeluarkan untuk biaya kontrak rumah. 
Tabel 1. Karakteristik Keluarga

\begin{tabular}{|c|c|c|}
\hline Karakteristik & $\mathbf{n}$ & $\%$ \\
\hline \multicolumn{3}{|l|}{ Pendidikan Ayah } \\
\hline SMP & 27 & 52,9 \\
\hline SMA & 24 & 47,1 \\
\hline \multicolumn{3}{|l|}{ Pendidikan Ibu } \\
\hline SMP & 43 & 84,3 \\
\hline SMA & 8 & 15,7 \\
\hline \multicolumn{3}{|l|}{ Pekerjaan Ayah } \\
\hline Guru & 1 & 2,0 \\
\hline Pekerja Kantoran & 5 & 9,8 \\
\hline Buruh & 11 & 21,6 \\
\hline Tidak Bekerja & 1 & 2,0 \\
\hline PNS/TNI/POLRI & 2 & 3,9 \\
\hline Pedagang & 10 & 19,6 \\
\hline Lainnya & 21 & 41,2 \\
\hline \multicolumn{3}{|l|}{ Pekerjaan Ibu } \\
\hline Guru & 1 & 2,0 \\
\hline Pekerja Kantoran & 1 & 2,0 \\
\hline Buruh & 2 & 3,9 \\
\hline Tidak Bekerja & 38 & 74,5 \\
\hline Pedagang & 6 & 11,8 \\
\hline Lainnya & 3 & 5,9 \\
\hline \multicolumn{3}{|c|}{ Kepemilikan Rumah } \\
\hline Milik Sendiri & 21 & 41,2 \\
\hline Kontrak & 30 & 58,8 \\
\hline
\end{tabular}

Sumber : Data Primer

Berdasarkan kuesioner yang digunakan dalam menentukan skor pengetahuan didapatkan bahwa skor rata-rata pengetahuan gizi mengalami kenaikan dari $62,39 \pm 12,05$ sebelum intervensi menjadi 72,31 $\pm 17,01$ sesudah intervensi (Tabel 2). Kenaikan ini berbeda secara bermakna antara sebelum dengan sesudah intervensi $(\mathrm{p}<0,05)$. Hal ini menandakan bahwa pendidikan gizi yang diberikan mampu meningkatkan pengetahuan gizi.

Hasil yang sama dengan penelitian ini didapatkan juga pada hasil penelitian Zulaekah (2007), yang menyebutkan bahwa intervensi suplementasi zat besi pada anak anemia yang disertai dengan pendidikan gizi dapat meningkatkan pengetahuan gizi tentang anemia pada anak dari nilai rata-rata 55,23\% menjawab benar menjadi $71,21 \%$ menjawab benar. Peningkatan ini lebih besar bila dibandingkan dengan kelompok yang tidak mendapatkan pendidikan gizi yaitu dari 56,33\% menjawab benar menjadi 58,22 \% menjawab benar. Peneliti ini juga menyimpulkan bahwa kelompok yang mendapatkan suplementasi zat besi seminggu dua kali dan pendidikan gizi dua minggu sekali mempunyai tingkat pengetahuan gizi lebih baik dibanding kelompok yang hanya mendapatkan suplementasi dua kali seminggu saja tanpa mendapatkan pendidikan gizi. Lebih lanjut, penelitian Zulaekah pada tahun 2012 menemukan bahwa pendidikan gizi dengan menggunakan booklet meningkatkan pengetahuan gizi sebesar 17,44 poin.

Penelitian tentang pengaruh suplementasi zat gizi dan pendidikan gizi terhadap pengetahuan gizi, pemenuhan zat gizi dan perbaikan status besi (Dwiriani, 2011) menyatakan bahwa pendidikan gizi meningkatkan skor pengetahuan gizi 28,6 dan 8,7 nilai MAR (Mean Adequacy Ratio) pada kelompok SGP (Suplementasi Multi Gizi Mikro Plus Pendidikan Gizi) dan secara signifikan lebih tinggi dibandingkan kelompok SG (Suplementasi Multi Gizi Mikro) dan Kontrol. Penelitian Armani (2006), juga menemukan bahwa pendidikan gizi meningkatkan pengetahuan tentang gizi sehat dan pilihan gaya hidup terhadap makanan. Penelitian Moore (2009), juga menemukan bahwa skor pengetahuan gizi pada remaja putri dan ibu meningkat secara nyata setelah diberikan program intervensi gizi.

Berdasarkan hasil food recall 24 jam yang dilakukan sebanyak dua kali didapatkan bahwa asupan protein menurun dari $65,48 \pm 41,67$ menjadi 53,25 $\pm 35,54$. Asupan vitamin $C$ menurun dari 58,78 $\pm 95,38$ menjadi $33,53 \pm 53,05$. Asupan vitamin A menurun dari $717,27 \pm 818,55$ menjadi $574,32 \pm 585,36$. Asupan asam folat menurun dari $162,77 \pm 129,15$ menjadi $131,04 \pm 98,66$. Asupan besi menurun dari $10,05 \pm 9,97$ menjadi $8,54 \pm 11,42$. Asupan zink menurun dari $6,98 \pm 5,00$ menjadi $5,31 \pm 4,15$. Asupan tembaga menurun dari $117,23 \pm 102,89$ menjadi 98,83 $\pm 160,76$ (Tabel 2).

Kemungkinan penyebab penurunan asupan zat gizi ini adalah pada masa libur sekolah, remaja putri tidak bisa mendapatkan makanan lain di luar dari makanan yang disediakan di rumah. Bila masa sekolah, remaja putri bisa mendapatkan makanan lain dari 
Tabel 2. Skor Pengetahuan dan Asupan Gizi Sebelum dan Sesudah Intervensi

\begin{tabular}{|c|c|c|c|c|c|}
\hline \multirow{3}{*}{ Variabel } & \multicolumn{4}{|c|}{ Kelompok Intervensi ( $\mathrm{n}=51$ orang) } & \multirow{3}{*}{$p$} \\
\hline & \multicolumn{2}{|c|}{ Sebelum } & \multicolumn{2}{|c|}{ Sesudah } & \\
\hline & Mean & $S D$ & Mean & $S D$ & \\
\hline Skor Pengetahuan Gizi & 62,39 & 12,05 & 72,31 & 17,01 & $<0,001^{\mathrm{a}^{*}}$ \\
\hline Protein (gr) & 65,48 & 41,67 & 53,25 & 35,54 & $0,051^{\mathrm{a}}$ \\
\hline Vitamin C (mg) & 58,78 & 95,38 & 33,53 & 53,05 & $0,097^{\mathrm{b}}$ \\
\hline Vitamin A (RE) & 717,27 & 818,55 & 574,32 & 585,36 & $0,771^{\mathrm{a}}$ \\
\hline Asam Folat $(\mu \mathrm{g})$ & 162,77 & 129,15 & 131,04 & 98,66 & $0,163^{\mathrm{a}}$ \\
\hline Besi (mg) & 10,05 & 9,97 & 8,54 & 11,42 & $0,269^{a}$ \\
\hline Zink $(\mu \mathrm{g})$ & 6,98 & 5,00 & 5,31 & 4,15 & $0,092^{\mathrm{b}}$ \\
\hline Tembaga $(\mu \mathrm{g})$ & 117,23 & 102,89 & 98,83 & 160,76 & $0,039^{a^{*}}$ \\
\hline
\end{tabular}

Sumber : Data Primer

jajanan sedangkan bila masa libur sekolah, remaja putri tidak bisa mendapatkannya dikarenakan orang tua tidak memberikan uang jajan. Selain itu, selama libur sekolah, remaja putri juga jarang sarapan pagi. Hal ini dikarenakan adanya anggapan bahwa bila tidak sekolah, maka tidak perlu sarapan pagi karena tidak beraktivitas lebih dari biasanya. Menurut Arisman (2010), mengonsumsi beberapa makanan di pagi hari, mencoba makanan baru dan menyeleksi makanan jajanan yang bergizi dapat menciptakan pola kebiasaan pangan yang baik pada remaja.

Hasil uji statistik membuktikan bahwa tidak ada perbedaan bermakna asupan protein, vitamin $\mathrm{C}$, vitamin $\mathrm{A}$, asam folat, besi dan zink sebelum dan sesudah intervensi $(\mathrm{p}>0,05)$, namun ada perbedaan bermakna asupan tembaga sebelum dan sesudah intervensi $(p<0,05)$. Meskipun secara statistik menunjukkan ada perbedaan bermakna, namun rata-rata asupan tembaga pada sampel mengalami penurunan.

Hal ini menunjukkan bahwa pendidikan gizi yang diberikan tidak mampu mengubah pola makan remaja putri dikarenakan penyediaan makanan bergantung pada penyediaan makanan yang disediakan oleh orang tua di rumah. Orang tua berperan besar dalam mengatur kebiasaan makan anaknya. Meskipun anak mendapatkan pendidikan gizi, bila orang tuanya tidak mendapatkan pendidikan gizi, maka konsumsi makanan cenderung tidak akan berubah. Selain itu, tingkat sosial ekonomi keluarga juga memengaruhi ketersediaan makanan di

rumah. Menurut Hadi (2005), tingkat sosial ekonomi yang membaik dalam keluarga akan semakin mempermudah ibu untuk mendapatkan berbagai macam bahan makanan yang sesuai dengan pilihan dan selera. Hasil penelitian Kim (2014), juga menyatakan bahwa kecenderungan prevalensi anemia semakin rendah seiring dengan semakin meningkatnya tingkat pendapatan pada keluarga remaja putri di Korea. Hal ini dikarenakan tiap individu pada keluarga dengan tingkat pendapatan tinggi banyak mengonsumsi zat besi dan vitamin C.

Pangan hewani merupakan sumber zat besi terbaik karena kandungan zat besi yang lebih tinggi dan mempunyai bioavalabilitas lebih tinggi yang lebih baik dalam absorpsi zat besi dibanding zat besi dalam pangan hewani. Zat besi dalam pangan hewani adalah besi hem yang dapat diabrospsi dengan baik. Sementara itu, dalam pangan nabati zat besinya adalah besi non hem. Absrobsi besi non hem lebih rendah dan sangat dipengaruhi oleh komponen diet lainnya (Barasi, 2009). Selama masa remaja, pertumbuhan cepat dan aktivitas tinggi dapat memengaruhi kebutuhan gizi. Perkembangan fisik dan psikososial juga dapat memengaruhi pilihan makanan pada periode ini. Remaja mengalami peningkatan kemandirian dan teman sebaya mudah memengaruhi kelompok ini, sehingga menyebabkan remaja lebih sulit untuk merencanakan makanan yang sehat. Inilah faktor yang dapat memengaruhi timbulnya masalah kesehatan terkait gizi pada remaja (Herbold, 2013).

Perlu diperhatikan kombinasi makanan sehari-hari, yang terdiri dari campuran sumber 
besi yang berasal dari hewan dan tumbuhtumbuhan serta sumber zat gizi lainnya yang dapat membantu absorbsi. Selanjutnya, menu sebaiknya terdiri atas nasi, daging/ikan/ ayam, kacang-kacangan serta sayur-sayuran dan buah-buahan yang kaya akan vitamin $\mathrm{C}$ (Almatsier, 2007). Jenis dan jumlah zat-zat gizi harus disediakan dengan cukup oleh makanan. Hidangan lengkap terdiri dari bahan makanan pokok, lauk pauk, sayuran, dan buah. Penderita defisiensi besi umumnya memperlihatkan hidangan yang kurang mengandung daging atau bahan makanan hewan lain dan juga kurang sayur dan daun berwarna hijau dalam konsumsi makan (Sediaoetama, 2009).

Rendahnya asupan gizi pada penelitian ini dikarenakan ketersediaan pangan dalam keluarga tidak berubah yang disebabkan oleh faktor pendidikan orang tua dan pendapatan keluarga. Hal ini sesuai dengan penelitian Gultom (2008) yang menyatakan bahwa faktor penghasilan keluarga berhubungan bermakna dengan kenaikan kadar hemoglobin anak balita (OR=3,04, 95\%CI: 1,12-8,23). Chang (2009), mendapatkan bahwa asupan zat gizi pada kelompok anemia lebih rendah daripada kelompok tidak anemia. Rata-rata asupan zat gizi kelompok anemia dibandingkan dengan tidak anemia terdiri dari besi (sebesar $42,3 \%$ dari asupan zat gizi yang dianjurkan pada kelompok anemia dan 49,3\% pada kelompok tidak anemia), vitamin C (sebesar 52,7\% dari asupan yang dianjurkan pada kelompok anemia dan $64,6 \%$ pada kelompok tidak anemia), calcium (sebesar $38,1 \%$ dari asupan yang dianjurkan dan $40,4 \%$ pada kelompok tidak anemia) dan vitamin B1 (sebesar $75,7 \%$ dari asupan yang dianjurkan pada kelompok anemia dan 83,9\% pada kelompok tidak anemia).

Selain itu, hasil penelitian Eicher (2009), menemukan bahwa anak yang asupan makanannya kurang menyebabkan kemungkinan anemia sebesar 2,95 kali dibandingkan anak yang asupan makanannya baik. Hasil penelitian Gupta (2012), menemukan bahwa tingginya prevalensi anemia pada remaja di daerah perkotaan disebakan oleh kebiasaan makan remaja di perkotaan yang buruk dibandingkan dengan kebiasaan makan remaja di pedesaan. Penelitian Zulaekah (2007), memperlihatkan bahwa intervensi pendidikan gizi pada anak dua minggu sekali, serta orang tua/wali dan guru kelas satu bulan sekali dalam waktu 3 bulan belum bisa mengubah asupan zat gizi dari makanan terutama zat besi pada anak. Ibu mempunyai peran penting dalam mengatur dan mengendalikan arus makanan dalam keluarga, sehingga pengetahuan ibu khususnya tentang gizi sangat menentukan terhadap pola konsumsi makan dalam keluarga, khususnya kebiasaan makan anak. Walaupun pengetahuan gizi ibu akan meningkat dengan pemberian pendidikan gizi, namun tingkat sosial ekonomi terutama pendapatan keluarga yang rendah akan menjadi tantangan tersendiri bagi ibu terutama dalam memilih bahan makanan yang akan disajikan dengan keuangan yang terbatas.

Penelitian ini membuktikan bahwa pendidikan gizi yang diberikan dengan metode ceramah tanya jawab dengan bantuan booklet berpotensi dalam meningkatkan pengetahuan remaja putri tentang anemia. Namun tidak berpotensi dalam meningkatkan asupan gizi protein, vitamin $\mathrm{C}$, vitamin $\mathrm{A}$, asam folat, besi, zink dan tembaga.

\section{Penutup}

Intervensi pendidikan gizi yang diberikan meningkatkan skor pengetahuan gizi remaja putri, tetapi tidak mengubah asupan gizi protein, vitamin $\mathrm{C}$, vitamin $\mathrm{A}$, asam folat, besi, zink dan tembaga. Ada perbedaan bermakna skor pengetahuan gizi remaja putri yang anemia sebelum dan sesudah diberikan pendidikan gizi. Namun, tidak ada perbedaan bermakna asupan gizi remaja putri yang anemia sebelum dan sesudah diberikan pendidikan gizi, kecuali asupan tembaga.

\section{Ucapan Terima Kasih}

Ucapan terima kasih disampaikan kepada pihak sekolah yang telah memberikan izin selama penelitian, dan kepada pihak Puskesmas Simalingkar yang telah bekerja sama dalam melaksanakan penelitian hingga selesai.

\section{Daftar Pustaka}

Almatsier, S., 2007. Prinsip Dasar Ilmu Gizi. Jakarta: PT Gramedia Pustaka Utama.

Arisman, 2010. Gizi dalam Daur Kehidupan. Jakarta: EGC. 
Armani, R., dan Soflaei, M. 2006. Nutrition Education Alone Improves Dietary Practices but Not Hematologic Indices of Adolescent Girls in Iran. Food Nutrition Bulletin, 27(3):260-4.

Barasi, M.E., 2009. At a Glance: Ilmu Gizi. Jakarta: Erlangga.

Chang, M.C., et al. 2009. A Study of Prevalence of Anemia in Adolescent Girls and Reproductive-Age Women in Kuala Lumpur. Archives of Medical Science (AMS), 5(1):6368.

Departemen Kesehatan RI, 2005. Gizi dalam Angka. Jakarta: Departemen Kesehatan.

Dwiriani, C.M., Rimbawan, Hardinsyah, Riyadi, H., dan Martianto, D., 2011. Pengaruh Pemberian Zat Multi Gizi Mikro dan Pendidikan Gizi terhadap Pengetahuan Gizi, Pemenuhan Zat Gizi dan Status Besi Remaja Putri. Jurnal Gizi dan Pangan, 6(3): 171-177.

Eicher-Miller, et al. 2009. Food Insecurity is Associated with Iron Deficiency Anemia in US Adolescents. Am. J. Clin Nutr., 90:135871.

Goldberg, J.P.W., Catherine, M. 2015. Lessons Learned From Two Decades Of Research In Nutrition Education And Obesity Prevention: Considerations For Alcohol Education. Journal Patient Education and Counseling, 98(9); 55-62.

Gultom, E.H, 2008. Faktor-Faktor yang Berhubungan dengan Kenaikan Kadar Hemoglobin Anak Balita Anemia Setelah Suplementasi Besi 12 Minggu di Posyandu Kelurahan Pisangan Baru Matraman Jakarta Timur 2007. Tesis. Program Pascasarjana Studi Epidemiologi Fakultas Kesehatan Masyarakat Universitas Indonesia.

Gupta, A., et al. 2012. Anemia Among Adolescent Girls in Shimla Hills of North India: Does BMI and Onset of Menarche have A Role? Indian Journal of Medical Sciences 66(5\&6): 126-130.

Hadi, S., Sulistyowati, E., Mifbakhudin. 2005. Hubungan Pendapatan Perkapita, Pengetahuan Gizi Ibu dan Aktivitas Fisik dengan Obesitas Anak Kelas 4 dan 5 di SD Hj. Isriati Baiturrahman Kota Semarang. Jurnal Kesehatan Masyarakat Indonesia Fakultas Kesehatan Masyarakat Universitas Muhammadiyah Semarang, 2(1):7-12.

Herbold, N.H., dan Edelstein, S., 2013. Nutrisi. (translation). Jakarta: EGC.

Karavetian, M., et al. 2015. Journal Patient Education and Counseling, 98 (9): 1116-1122.

Kementrian Kesehatan RI, 2014. Riset Kesehatan Dasar 2013. Jakarta: Kementerian Kesehatan Republik Indonesia.

Kim, J.Y., et al. 2014. Relationship between Socioeconomic Atatus and Anemia Prevalence in Adolescent Girls based on the Fourth and Fifth Korea National Health and Nutrition Examination Surveys. European Journal of Clinical Nutrition, 68:253-258.

Moore, J.B, et al. 2009. The Effect of a Nutrition Education Program on the Nutritional Knowledge, Hemoglobin Levels, and Nutritional Status of Nicaraguan Adolescent Girls. Public Health Nursing, 26(2):144-152.

Milman, N., 2011. Anemia-Still a Major Health Problem in Many Parts of the World! Review Article. Ann Hematol, 90:369-377.

Purwati, Y., Rachman, I.T., dan Akhmadi. 2015. Pendidikan Seksual dan Perilaku Pemenuhan Kebutuah Seksual Pasangan Masa Kehamilan. Jurnal Kesehatan Masyarakat, 10(2):178-185.

Sediaoetama, A.D., 2009. Ilmu Gizi untuk Mahasiswa dan Profesi. Jakarta: Dian Rakyat.

WHO, 2008. Worldwide Prevalence of Anemia 19932005: WHO Global Database on Anemia.

WHO, 2011. Prevention of Iron Deficiency Anemia in Adolescents: Role of Weekly Iron and Folic Acid Suplementation.

Zulaekah, Siti, 2007. Efek Suplementasi Besi, Vitamin $C$ dan Pendidikan Gizi terhadap Perubahan Kadar Hemoglobin Anak Sekolah Dasar yang Anemia di Kecamatan Kartasura Kabupaten Sukoharjo. Tesis. Semarang: Universitas Diponegoro Semarang Pasca Sarjana. ,2012. Pendidikan Gizi dengan Media Booklet terhadap Peningkatan Pengetahuan Gizi. Jurnal Kesehatan Masyarakat, 7(2):127133. 